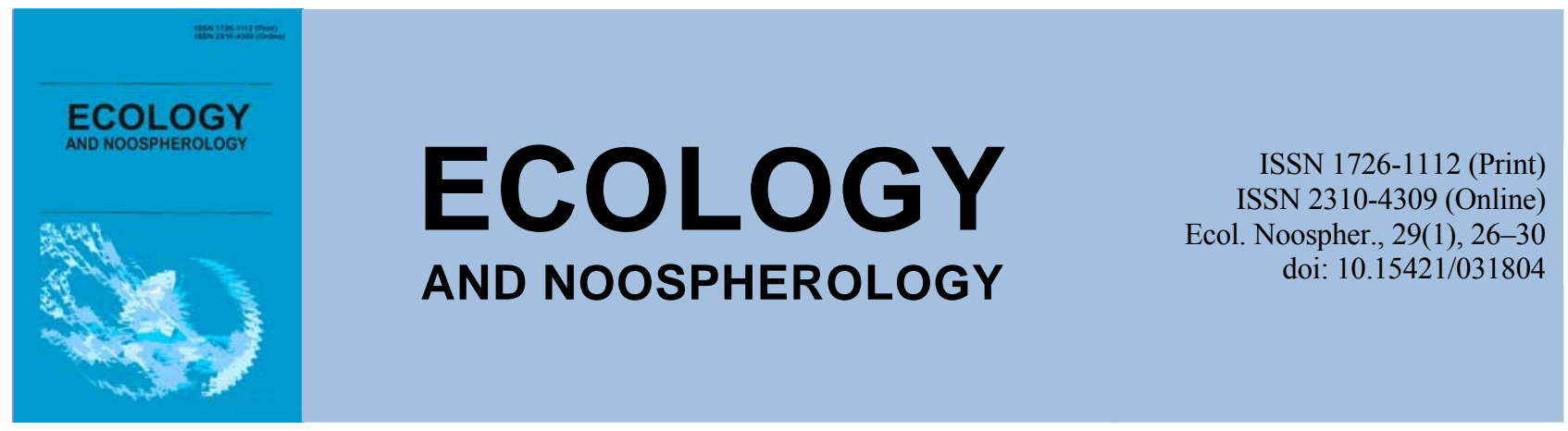

\title{
The birds communities functional structure dynamics in the ash individual consortia under the influence of the climatic factors annual dynamics
}

\author{
O. L. Ponomarenko
}

Oles Honchar Dnipro National University, Dnipro, Ukraine

Article info

Received 20.03.2018

Received in revised form 27.03.2018

Accepted 02.04.2018

Oles Honchar Dnipro

National University,

Gagarin Ave., 72, Dnipro, 49010, Ukraine.

Tel.: +38-066-439-05-72

E-mail:aponomar@ua.fm
Ponomarenko, O. L. (2018). The birds communities functional structure dynamics in the ash individual consortia under the influence of the climatic factors annual dynamics. Ecology and Noospherology, 29(1), 26-30. doi:10.15421/031804

The studying of the connections between the birds and consortia is impossible without their dynamics research. The amount of organisms that are part of the consortium is large enough and their significant part is active only for some year part, the full extent of the links detection is impossible without the seasonal dynamics analyses. The article is devoted to the bird communities in individual consortia of such edificator of the linden-ash-tree oak groves, as the ash (Fraxinus excelsior L.). This work material was collected in different seasons of 2004-2010 years in a lindenash oak grove on the test plot No. 209 of the ecological profile of the NSC «Belgard Prisamare International Biospheric stationary», Novomoskovsk district, Dnepropetrovsk region. The individual consortia of 183 ash examples of three age conditions (virgins - virg, young generative $\mathrm{gl}$, mature and old generative individuals $-\mathrm{g} 2-\mathrm{g} 3$ ) were investigated. The ash consortia have in their composition topomorphs of the woodbirds, edge birds, and ubiquitous birds. Woodbirds are the dominant birds group. They completely dominate in the virginia ash consortia and significantly prevail over the ubiquitous on young generative trees. An edge birds group appears only on old and mature generative trees. Climamorphs are represented by year-round and seasonal bird species. The ratio of these two groups in consortia varies during the year, but in general, year-round bird species dominate. Therefore, the interaction system of the birds with ash has is quit stable. The virginal ash has seasonal species only in summer and autumn. The generative ashes of all the categories have the both climamorphe groups during the year. This indicates that a stable system of the birds with ash consortive interactions has been formed only with the fruiting beginning. The trophomorphs are the most diverse group of the morphs. Such biomorphs as zoophages, phytophages, omnivores are represented in the ash consortium. Within these biomorphs, second-order biomors were identified: seed-eaters, fruit-eaters, observers, sweepers, deep sweepers. The third order trophomorphs were also distinguished as the size links. The trophomorphs greatest variety was recorded for the young generative trees 13 trophomorphs of the second and third orders. The mature and old generative trees have 12 trophomorphs. The virginal trees - only 2 trophomorphs. This is partly due to the neighboring tree species influence in the tree stand composition. It was found that the virgin trees have the lowest biomorphic diversity of the birds, and the generative trees have the highest one. This distinguishes ash from the other tree species. The reason of this is that the mature and old generative ash (g2-g3) has a crown located above the upper layer. The semi-open architecture of this tree crown is also facilitate to this. In such conditions birds don't find enough places for their protection from predators, so they spend a little time on this tree, and don't delay in its crown. The young generative ash crowns are within the upper and middle tree layers, so they have safer conditions for birds. The studies conducted in different seasons, also has found an interesting feature of the ash. Unlike other species, the ash is the least attractive for birds in the fall. In winter the birds visit this tree quite actively. The ash high fecundity and its seeds remaining on the tree branches in winter are the reason of this fact. As a result, some birds feed the ash tree fruits, while the other birds extract insects-phytophagous from it. The results of the research indicate that the ash is less attractive for the birds than the tired crown trees, such as oak, maple, linden. On the other hand, a significant part of the birds time budget on ash is spent for surveillance. Birds use ash as a place for review and control of their site. Therefore, ash can be recommended as an additional species in the artificial tree-stands creation. 


\title{
Динаміка функціональної структури угруповань птахів індивідуальних консорцій ясена звичайного під впливом річної динаміки кліматичних факторів
}

\author{
О. Л. Пономаренко
}

\author{
Дніпровський національний університет імені Олеся Гончара, Дніпро, Украӥна
}

Стаття присвячена угрупованням птахів в індивідуальних консорціях такого едифікатора липово-ясеневих дібров, як ясен звичайний (Fraxinus excelsior L.). Матеріал даної роботи збирався у різні пори року протягом 2004-2010 років у липово-ясеневій діброві із зірочником на пробній площі № 209 екологічного профілю ННЦ «Присамарський міжнародний біосферний стаціонар ім. О. Л. Бельгарда», Новомосковський район, Дніпропетровська область. Дослідженням було піддано індивідуальні консорції 183 екземплярів ясена звичайного трьох вікових станів (віргінільні особини - virg, молоді генеративні - gl, зрілі та старі генеративні особини - g2-g3). У результаті досліджень було виявлено, що біоморфічне різноманіття птахів у консорціях ясена $є$ найменшим у дерев віком virg, найбільше - g1. Це відрізняє ясен від інших деревних порід. Причиною цього є те, що зрілий та старий генеративний ясен (g2-g3) має крону, розташовану вище верхнього ярусу. Також цьому сприяє напіважурна архітектоніка крони цього дерева. У таких умовах птахи не знаходять достатньо місць для схову від хижаків, тому витрачають на це дерево небагато часу, не затримуючись надовго в його кроні. Крони молодого генеративного ясена, навпаки, розташовані в гущі верхнього та середнього ярусів і тому мають більш безпечні умови для птахів. Дослідження, проведені в різні пори року, виявили цікаву особливість ясена. На відміну від деяких інших порід, ясен $є$ найменш привабливим для птахів восени. Взимку ця порода відвідується птахами досить активно. Причиною цього $є$ висока плодючість ясена і те, що його насіння залишається на гілках дерева в зимовий період. У результаті частина птахів живиться плодами ясена, а інша здобуває в них комах-фітофагів. Результати досліджень свідчать про те, що ясен поступається у привабливості для птахів щільнокронним породам, таким як дуб звичайний, клени, липа. 3 іншого боку, значна частина бюджету часу, витраченого птахами на ясені, використана на такий вид активності, як спостереження. Птахи використовують ясен як місце огляду та контролю за ділянкою. Тому ясен можна рекомендувати як додаткову породу при створенні штучних деревостанів.

Ключові слова: птахи; ясен звичайний; консорція; консортивні взаємодії; динаміка протягом року

\section{Вступ}

Дослідження консортивних зв'язків птахів і консорцій взагалі неможливе без дослідження їхньої динаміки. Враховуючи той факт, що коло організмів, які входять у склад консорції, досить широке і значна частина їх активна тільки частину року, виявлення повного обсягу зв'язків неможливе без аналізу сезонної динаміки. Особливо це важливо для вивчення роботи окремих концентрів. Загалом наукові праці щодо участі птахів у системі консортивних зв'язків досить численні (Ponomarenko, 2005, 2006, 2007; Tryfanova, Kunah, Zhukov, 2015; Yuzyk, Chaplygina, 2015; Chaplygina, Yuzyk, Savynska, 2016a, 2016b). 3 іншого боку, у цих наукових працях висвітлюються питання розвитку системи консортивних зв'язків птахів протягом онтогенезу ядра консорції, функціональний склад птахів-консортів, їх чисельність та просторовий розподіл, але питання міжсезонної динаміки консортивних зв'язків птахів в індивідуальних консорціях практично не розглядалися. Тому дане дослідження, на нашу думку, є досить актуальним 3 погляду всебічного висвітлення всіх аспектів існування консорцій.

\section{Матеріали та методи досліджень}

В основу методологічного підходу досліджень покладено учення В. М. Сукачова (Sukachev, 1972) про біогеоценоз, типологію штучних i природних лісів степової зони О. Л. Бельгарда (Belgard, 1971), учення В. І. Беклемішева (Beklemishev, 1951), Л. Г. Раменського (Ramenskiy, 1952), В. В. Мазинга (Mazing, 1966) про консорції.

Матеріал даної роботи збирався в різні пори року протягом 2004-2010 pp. у липово-ясеневій діброві із зірочником (пробна площа № 209 екологічного профілю ННЦ «Присамарський міжнародний біосферний стаціонар ім. О. Л. Бельгарда»). Для дослідження консортивних зв'язків птахів за об'єкти було обрано індивідуальні консорції ясена звичайного (Fraxinus excelsior L.). Дослідженням було піддано індивідуальні консорції
183 екземплярів ясена звичайного трьох вікових станів (віргінільні особини - virg, молоді генеративні - gl, зрілі та старі генеративні особини - g2-g3). Віковий стан детермінантів консорції визначався за Смирновою зі співавторами (Smirnova, Zaugolnova, Taronova, Falikov, 1976). Як основний методичний прийом для вивчення консортивних зв'язків птахів було використане хронометрування бюджету часу птахів (Dolnik, 1982) у модифікації, запропонованій О. Л. Пономаренко (Ponomarenko, 2005). Біоморфічний аналіз проводився за системою біоморф М. П. Акімова (Akimov, 1954). Матеріал збирався по чотирьох сезонах: весною, влітку, восени та взимку.

Ясен звичайний (Fraxinus excelsior) $є$ одним 3 едифікаторів липово-ясеневих дібров Степового Придніпров'я. Поряд 3 дубом звичайним ясен утворює верхній ярус досліджуваних дібров (Belgard, 1971). Ця деревна порода значно відрізняється від дуба звичайного. Головною iї особливістю $\epsilon$ напіважурний тип архітектоніки крони (Belgard, 1960). Відповідно крона ясена пропускає багато світла, що може негативно впливати на формування лісового типу мікроклімату (Tkachenko, 1955). Характерними особливостями ясена також $€$ :

1) високий рівень тіньовитривалості підросту цієї породи (Tkachenko, 1955), що призводить до того, що, на відміну від дуба, ясен успішно відновлюється на неосвітлених позиціях і його підріст у липово-ясеневих дібровах є досить численним;

2) досить раннє очищення від нижніх гілок стовбура дерева (до 75 \% загальної висоти) (Tkachenko, 1955), що зменшує обсяг і без того не дуже великої крони ясена.

Ці особливості онтогенезу призводять до того, що ясен звичайний створює мозаїчну структуру в моноценозі липово-ясеневих дібров, формуючи своєрідні світлові «вікна». Відсутність щільної крони у ясена призводить до малої кількості місць схову для птахів. Усе вищевказане відповідно впливає і на систему консортивних зв'язків цієї деревної породи. 
Цвітіння ясена настає до початку розпускання листя. Дозрівання плодів відбувається восени (Tkachenko, 1955). На відміну від дуба, насіння ясена залишається на дереві протягом осені та зими. Плодоносить ясен дуже рясно (Tkachenko, 1955). Ці особливості відповідно впливають на функціонування мероконсорцій генеративних органів цієї деревної породи і участь у них птахів. Ураховуючи все вищевказане, можна припустити, що птахи не $є$ активними консортами цієї породи.

На досліджуваній площі ясен звичайний представлений паростевою віком пенерацією под 100 років (Grigorenko, Lyindya, 1977).

Висота досліджуваних ясенів коливалася в межах 2429,5 м у зрілому та старому генеративному стані $(g 2-g 3)$, $11-17$ м - у молодому генеративному стані $(g l)$, та 3-7 м у віргінільному стані. Розмах крони коливався в межах 10-18 м, 4-7 м, 2-3,5 м відповідно.

\section{Результати та їх обговорення}

Біоморфічна структура консортивних угруповань птахів ясена формується під впливом декількох факторів, серед яких є специфічна архітектоніка крони цієї деревної породи, панування ясена у верхньому ярусі, обламування нижніх гілок.

Біоморфічна структура консортивного угруповання птахів віргінільного ясена формується перш за все під впливом його просторового розташування в нижньому ярусі на тіньових позиціях.

На відміну від дуба звичайного, ясен віком virg має тільки одну топоморфу птахів - дріміофілів (табл. 1). Не зафіксовано жодного випадку проникнення представників топоморф, не властивих для липово-ясеневої діброви. Розташування у «глибині» діброви значно зменшує i коливання часткової участі клімаморфічних груп. Окрім сезонників у консорції беруть участь тільки деякі види морфи літніх видів-дріміофілів (табл. 1), що суттєво збіднює консорцію віргінільного ясена.

\section{Таблиця 1}

Сезонна динаміка топо- та клімаморфічного складу консортивних угруповань птахів у консорції віргінільного ясена

\begin{tabular}{lcccc}
\hline Біоморфи & \multicolumn{5}{c}{ Часткова участь у бюджеті часу, \% } \\
\cline { 2 - 5 } ІІ порядку & Літо & Осінь & Зима & Весна \\
\hline \multicolumn{5}{c}{ Топоморфи } \\
\hline Дріміофіли & 100 & 100 & 100 & 100 \\
Узлісники & - & - & - & - \\
Убіквісти & - & - & - & - \\
\hline Усього & 100,00 & 100,00 & 100,00 & 100,00 \\
\hline \multicolumn{5}{c}{ Клімаморфи } \\
\hline Цілорічні & 50 & 20,25 & 100 & 100 \\
види & \multicolumn{5}{c}{ Сезонники } & 50 & 79,75 & - & - \\
\hline Усього & 100,00 & 100,00 & 100,00 & 100,00 \\
\hline
\end{tabular}

Характерною $є$ також відсутність участі літніх видівсезонників весною, під час формування гніздових угруповань птахів. Віргінільний ясен не створює середовища, яке приваблює значну кількість птахів. Відповідно консорція віргінільного ясена протягом року не виявляє стабільності. Трофоморфічна структура віргінільного ясена також істотно відрізняється від такої у дуба звичайного. У складі трофомор є тільки зоофаги, причому 3 дуже малим діапазоном маси. Домінуючою $€$ друга розмірна ланка зоофагів, що $є$ типовим для нижнього ярусу липово-ясеневої діброви (табл. 2).

Ураховуючи малу кількість листової поверхні ясена $g l$, можна вважати закономірним той факт, що перша розмірна ланка лише літом (у період максимального розвитку трофічної бази зоофагів) незначною мірою виявляє свою активність у консорції ясена. Таким чином, функціональне різноманіття в консорції віргінільного ясена дуже низьке порівняно з дубом звичайним. Віргінільний ясен $є$ тільки супутнім ядром консорції для птахів.

\section{Таблиця 2}

Сезонна динаміка трофоморфічного складу консортивних угруповань птахів у консорції віргінільного ясена

\begin{tabular}{|c|c|c|c|c|c|c|}
\hline \multirow{2}{*}{$\begin{array}{l}\text { Трофо- } \\
\text { морфи } \\
\text { І по- } \\
\text { рядку }\end{array}$} & \multirow{2}{*}{$\begin{array}{c}\text { Трофо- } \\
\text { морфи } \\
\text { II по- } \\
\text { рядку }\end{array}$} & \multirow{2}{*}{$\begin{array}{l}\text { Трофо- } \\
\text { морфи } \\
\text { III по- } \\
\text { рядку }\end{array}$} & \multicolumn{4}{|c|}{$\begin{array}{c}\text { Часткова участь } \\
\text { у бюджеті часу, \% }\end{array}$} \\
\hline & & & Літо & Осінь & Зима & Весна \\
\hline \multirow{4}{*}{ Зоофаги } & $\begin{array}{c}\text { Обшар- } \\
\text { щики }\end{array}$ & 1 & 16,67 & 7,59 & - & - \\
\hline & $\begin{array}{l}\text { Обшар- } \\
\text { щики } \\
\end{array}$ & 2 & 83,33 & 92,41 & 100 & 100 \\
\hline & \multicolumn{2}{|c|}{ Зоофагів усього } & 100,00 & 100,00 & 100,00 & 100,00 \\
\hline & \multicolumn{2}{|l|}{ Усього } & 100,00 & 100,00 & 100,00 & 100,00 \\
\hline
\end{tabular}

Консортивне угруповання ясена віком $g 1$ більш розвинуте за рахунок виходу молодих генеративних екземплярів цієї породи в середній ярус і супровідного явища кондиціонування з боку консортивних угруповань інших порід.

Топоморфічна структура й надалі вирізняється пануванням дріміофілів (табл. 3), але за рахунок освітленої структури крони вперше улітку, під час інтенсивного обміну речовини та енергії у БГЦ, в яких беруть активну участь птахи, з'являються елементи із сусідніх біогеоценозів та екотонів. Участь цих елементів незначна і корінним чином не впливає на функціонування консорції. Клімаморфічна структура угруповання птахів-консортів вирізняється набагато інтенсивнішою динамікою, на відміну від віргінільного ясена (табл. 3). Цей факт пояснюється знову ж таки розташуванням крони молодого генеративного ясена в гущі середнього ярусу. Таким чином, біоморфічний аналіз підтверджує факт кондиціонування консорції ясена 3 боку консорцій інших порід. Вперше взимку з'являються сезонні види. Це свідчить про те, що мероконсорції генеративних органів ясена деяким чином підтримують птахів у жорстких умовах зимівлі.

\section{Таблиця 3}

Сезонна динаміка топо- та клімаморфічного складу консортивних угруповань птахів у консорції молодого генеративного ясена

\begin{tabular}{lcccc}
\hline Біоморфи & \multicolumn{5}{c}{ Часткова участь у бюджеті часу, \% } \\
\cline { 2 - 5 } ІІ порядку & Літо & Осінь & Зима & Весна \\
\hline \multicolumn{5}{c}{ Топоморфи } \\
\hline Дріміофіли & 98,62 & 100 & 100 & 100 \\
Узлісники & - & - & - & - \\
Убіквісти & 1,38 & - & - & - \\
\hline Усього & 100,00 & 100,00 & 100,00 & 100,00 \\
\hline \multicolumn{5}{c}{ Клімаморфи } \\
\hline Цілорічні & 62,95 & 44,39 & 99,64 & 46,29 \\
види & \multicolumn{5}{c}{0,36} & 53,21 \\
Сезонники & 37,05 & 55,61 & 0,36 \\
\hline Усього & 100,00 & 100,00 & 100,00 & 100,00 \\
\hline
\end{tabular}

Характерним $є$ досить низький рівень коливань участі сезонних видів порівняно 3 дубом (інтервал - 55,25 \%). Домінуючою залишається група цілорічних видів, це свідчить про те, що до умов середовища, які створює ясен, пристосувалася повною мірою досить мала кількість консортів-птахів. Завдяки цьому консортивне угруповання не реагує значною мірою на зміни навколишнього 
середовища, $є$ досить стабільним, але й малопродуктивним.

Трофоморфічна структура консортивного угруповання птахів молодого генеративного ясена, як і в такого ж дуба, уже представлена всіма трьома основними трофоморфічними групами: фіто-, зоо-, евріфагами. Це свідчить, що ясен може підтримувати досить різноманітне за функціями угруповання тварин (табл. 4). Характерною $€$ також досить висока частка фітофагів, але вони виявляють активність на ясені перш за все як топоконсорти.

\section{Таблиця 4}

Сезонна динаміка трофоморфічного складу консортивних угруповань птахів

у консорції молодого генеративного ясена

\begin{tabular}{|c|c|c|c|c|c|c|}
\hline \multirow{2}{*}{$\begin{array}{c}\text { Трофо- } \\
\text { морфи } \\
\text { I порядку }\end{array}$} & \multirow{2}{*}{$\begin{array}{c}\text { Трофо- } \\
\text { морфи } \\
\text { II порядку }\end{array}$} & \multirow{2}{*}{$\begin{array}{l}\text { Трофо- } \\
\text { морфи } \\
\text { III по- } \\
\text { рядку }\end{array}$} & \multicolumn{4}{|c|}{$\begin{array}{c}\text { Часткова участь } \\
\text { у бюджеті часу, \% }\end{array}$} \\
\hline & & & Літо & Осінь & Зима & Весна \\
\hline \multirow{3}{*}{ Фітофаги } & Насіннєїди & 5 & 57,95 & - & - & 29,66 \\
\hline & Плодоїди & 5 & - & - & 0,36 & - \\
\hline & Фітофагів & усього & 57,95 & - & 0,36 & 29,66 \\
\hline \multirow{4}{*}{ Всеїдні } & $\begin{array}{c}\text { Оглядаль- } \\
\text { ники }\end{array}$ & 6 & - & - & 0,43 & - \\
\hline & Обшарщики & 3 & 1,04 & - & - & - \\
\hline & Обшарщики & 5 & 0,13 & - & - & - \\
\hline & Всеїдних & усього & 1,17 & - & 0,43 & - \\
\hline \multirow{10}{*}{ Зоофаги } & $\begin{array}{c}\text { Глибокі } \\
\text { обшарщики }\end{array}$ & 3 & - & - & 1,03 & - \\
\hline & $\begin{array}{c}\text { Глибокі } \\
\text { обшарщики }\end{array}$ & 5 & - & - & 0,29 & - \\
\hline & $\begin{array}{c}\text { Глибокі } \\
\text { обшарщики }\end{array}$ & 6 & 2,66 & - & - & - \\
\hline & Обшарщики & 1 & 3,27 & 26,02 & - & - \\
\hline & Обшарщики & 2 & 24,33 & 73,98 & 97,61 & 57,86 \\
\hline & Обшарщики & 3 & 1,94 & - & 0,28 & 12,48 \\
\hline & Обшарщики & 5 & 0,40 & - & - & - \\
\hline & Засідники & 2 & 8,28 & - & - & - \\
\hline & \multicolumn{2}{|c|}{ Зоофагів усього } & 40,88 & - & 99,21 & 70,34 \\
\hline & Усього & & 100,00 & 100,00 & 100,00 & 100,00 \\
\hline
\end{tabular}

3 іншого боку, на відміну від дуба, ясен не має такого яскраво помітного домінування зоофагів. У свою чергу, зоофаги належним чином не контролюють популяції фітофагів, що може негативно впливати на стабільність консортивного угруповання в цілому.

Зоофаги мають неповний набір морф другого та третього порядку. Не відмічено обшарщиків 4-ї розмірної ланки. Взагалі не зафіксовано такої специфічної групи зоофагів, як мисливці. У цілому угруповання птахів молодого ясена досить різноманітне за функціональною структурою, хоча представництво окремих морф по сезонах дуже нестабільне, на відміну від дуба. Єдиною морфою, яка представлена протягом усього року, $\epsilon$ обшарщики другої розмірної ланки.

Консортивне угруповання зрілого та старого генеративного ясена (g2-g3) виявляє різноманітність топоморфічного складу тільки в період формування i функціонування гніздових угруповань птахів (табл. 5). Домінуючими протягом року $\epsilon$ дріміофіли. Якщо дуб звичайний залучає у своє угруповання крім пануючих дріміофілів ще в основному узлісників, то ясен убіквістів. Це пояснюється тим, що дуб контактує зі стабільним населенням прилеглих до липово-ясеневої діброви екотонів (узлісь), у той час як ясен, за рахунок освітленої крони, залучає птахів, які активно пересуваються між біогеоценозами, але їхня активність нестабільна. Фактично це залітання чужорідних елементів, які не мають стабільної основи в поведінці або живленні птахів. На користь цього свідчать і різкі коливання рівня активності убіквістів протягом сезону.

Необхідно відзначити той факт, що більш складною стає динаміка активності клімаморфічних груп (табл. 5). Консортивне угруповання починає досить активно залучати сезонні елементи, частково забезпечуючи стабільність потоків речовини та енергії.

\section{Таблиця 5}

Сезонна динаміка топо- та клімаморфічного складу консортивних угруповань птахів у консорції зрілого та старого генеративного ясена

\begin{tabular}{lcccc}
\hline Біоморфи & \multicolumn{4}{c}{ Часткова участь у бюджеті часу, \% } \\
\cline { 2 - 5 } ІІ порядку & Літо & Осінь & Зима & Весна \\
\hline \multicolumn{5}{c}{ Топоморфи } \\
\hline Дріміофіли & 90,64 & 100 & 100 & 92,54 \\
Узлісники & 0,56 & - & - & 7,46 \\
Убіквісти & 8,80 & - & - & - \\
\hline Усього & 100,00 & 100,00 & 100,00 & 100,00 \\
\hline \multicolumn{5}{c}{ Клімаморфи } \\
\hline Цілорічні & 63,94 & 97,84 & 98,73 & 45,42 \\
види & \multicolumn{5}{c}{1,27} & 54,58 \\
Сезонники & 36,06 & 2,16 & 100,00 \\
\hline Усього & 100,00 & 100,00 & 100,00 & 100 \\
\hline
\end{tabular}

Трофоморфічна структура (табл. 6) консортивного угруповання птахів зрілого та старого генеративного ясена бідніша, ніж у дуба звичайного, на 6 морф другого третього порядків. У середньому в кожному з досліджених сезонів року дуб має у складі своєї консорції більш ніж 10 трофоморф другого - третього порядків (Ponomarenko, 2006), у той час як ясен усього лише 6.

\section{Таблиця 6}

Сезонна динаміка трофоморфічного складу консортивних угруповань птахів у консорції зрілого та старого генеративного ясена

\begin{tabular}{|c|c|c|c|c|c|c|}
\hline \multirow{2}{*}{$\begin{array}{c}\text { Трофо- } \\
\text { морфи } \\
\text { I по- } \\
\text { рядку } \\
\end{array}$} & \multirow{2}{*}{$\begin{array}{c}\text { Трофо- } \\
\text { морфи } \\
\text { II порядку }\end{array}$} & \multirow{2}{*}{$\begin{array}{l}\text { Трофо- } \\
\text { морфи } \\
\text { III по- } \\
\text { рядку }\end{array}$} & \multicolumn{4}{|c|}{$\begin{array}{c}\text { Часткова участь у бюджеті } \\
\text { часу, \% } \\
\end{array}$} \\
\hline & & & Літо & Осінь & Зима & Весна \\
\hline \multirow{3}{*}{ Фітофаги } & Плодоїди & 4 & - & - & 1,27 & - \\
\hline & Насіннеїди & 5 & 6,66 & - & 0,11 & 34,37 \\
\hline & Фітофагів & усього & 6,66 & - & 1,38 & 34,37 \\
\hline \multirow{3}{*}{ Всеїдні } & $\begin{array}{c}\text { Оглядаль- } \\
\text { ники }\end{array}$ & 6 & 15,57 & - & 0,06 & - \\
\hline & $\begin{array}{c}\text { Обшар- } \\
\text { щики }\end{array}$ & 5 & 3,17 & - & - & 2,07 \\
\hline & Всеїдних & усього & 18,74 & - & 0,06 & 2,07 \\
\hline \multirow{10}{*}{ Зоофаги } & $\begin{array}{c}\text { Оглядаль- } \\
\text { ники } \\
\end{array}$ & 3 & - & - & - & 2,78 \\
\hline & $\begin{array}{c}\text { Оглядаль- } \\
\text { ники }\end{array}$ & 5 & 6,52 & - & - & - \\
\hline & $\begin{array}{c}\text { Глибокі } \\
\text { обшар- } \\
\text { щики } \\
\end{array}$ & 3 & - & - & 0,51 & - \\
\hline & $\begin{array}{c}\text { Глибокі } \\
\text { обшар- } \\
\text { щики } \\
\end{array}$ & 5 & 6,07 & - & 0,67 & 0,65 \\
\hline & $\begin{array}{l}\text { Обшар- } \\
\text { щики }\end{array}$ & 1 & 7,24 & - & 0,14 & 6,86 \\
\hline & $\begin{array}{l}\text { Обшар- } \\
\text { щики }\end{array}$ & 2 & 33,05 & 100,00 & 95,82 & 40,20 \\
\hline & $\begin{array}{c}\text { Обшар- } \\
\text { щики }\end{array}$ & 3 & 21,72 & - & 1,42 & 11,87 \\
\hline & Засідники & 2 & - & - & - & 1,20 \\
\hline & \multicolumn{2}{|c|}{ Зоофагів усього } & 74,60 & 100,00 & 98,56 & 63,56 \\
\hline & \multicolumn{2}{|l|}{ Усього } & 100,00 & 100,00 & 100,00 & 100,00 \\
\hline
\end{tabular}


Порівняно 3 дубом звичайним віком $g 2-g 3$, за середньорічними показниками ясен поступається частковою участю зоофагів $(84,18 \%$ проти $93,66 \%$ в дуба), незначно переважає за участю фітофагів (10,60\% проти $8,48 \%$ ) і більше ніж у 3 рази переважає за частковою участю еврифагів $(5,21$ проти 1,61$)$. Це $\epsilon$ свідченням нижчого рівня спеціалізації системи трофічних зв'язків у ясена звичайного.

Нижчий рівень різноманіття функціональної структури угруповання птахів-консортів ясена відображається і на рівні різноманіття окремих груп. Фітофаги в консорції дуба мають 5 трофоморф другого -третього порядків, у ясена -2 , еврифаги в консорції дуба -3 , у ясена -2 , зоофаги в дуба -11 , у ясена -8 . Не зафіксовано участі мисливців і повного спектру обшарщиків. 3 іншого боку, наявні глибокі обшарщики, які контролюють популяції фітофагів, що споживають деревину ясена.

\section{Висновки}

Підсумовуючи вищенаведене, можна стверджувати, що угруповання птахів індивідуальних консорцій ясена звичайного набувають свого найбільшого різноманіття у віці g1 (9 груп трофоморф $2-3$ порядків проти 8 у зрілого генеративного ясена). Це пов'язано з тим, що в цей період крона ясена ще не втратила нижніх гілок і знаходиться в межах верхнього ярусу, у той час як ясени віком g2-g3 часто піднімаються над третім ярусом

Найбільш різноманітними $є$ угруповання, які формуються весною та влітку, що пов'язано 3 періодом вегетації рослинності. На відміну від деяких інших порід, ясен має досить потужні угруповання взимку. Птахи, які $€$ зимовими консортами, беруть участь у першу чергу в мероконсорціях генеративних органів ясена.

Також слід зазначити, що ясен як ядро консорції протягом року поступається за більшістю показників дубу звичайному. Тому ясен можна рекомендувати лише як додаткову породу для створення штучних деревостанів.

\section{References}

Akimov, M. P. (1954). Biomorficheskiy metod izucheniya biotsenozov [Biomorphic method of biocoenoses studying]. Byulleten MOIP, 59 (3), 27-36 (in Russian).

Beklemishev, V. N. (1951). O klassifikatsii biogeotsenologicheskih (simfiziologicheskih) svyazey [On the classification of biogeocenotic (symphysiological) connections]. Byulleten MOIP, 55(5), 3-30 (in Russian).

Belgard, A. L. (1960). K teorii strukturyi iskusstvennogo lesnogo soobschestva $\mathrm{v}$ stepi [To the theory of the structure of an artificial forest community in the steppe]. Iskusstvennyie lesa stepnoy zonyi Ukrainyi. Kharkov. 17-32 (in Russian).

Belgard, A. L. (1971). Stepnoe lesovedenie [Steppe forest science]. Moscow (in Russian).

Chaplygina, A. B., Yuzyk, D. I., Savynska, N. O. (2016a). The robin, Erithacus rubecula (Passeriformes, Turdidae), as a component of autotrophic consortia of forest cenoses, Northeast Ukraine. Vestnik zoologii, 50(4), 369-378.

Chaplygina, A. B., Yuzyk, D. I., Savynska, N. O. (2016b). The robin, Erithacus rubecula (Passeriformes, Turdidae), as a component of heterotrophic consortia of forest cenoses, Northeast Ukraine. Part 2. Vestnik zoologii, 50(6), 493-502.
Dolnik, V. V. (1982). Metodyi izucheniya byudzhetov vremeni $i$ energii u ptits. [Methods of studying budgets of time and energy in birds]. Trudyi Zoologicheskogo institute, 113, 3-37 (in Russian).

Grigorenko, O. S., Lyindya, A. G. (1977). K ekologii duba chereshchatogo, yasenya obyiknovennogo, klenov ostrolistnogo, polevogo, i lipyi melkolistnoy, proizrastayuschih v dubravah Prisamarya [To the ecology of oak, ash, maples and linden, growing in the oak forests of Prisamarya]. Voprosyi stepnogo lesovedeniya i ohranyi prirodyi, 8, 75-81 (in Russian).

Mazing, V. V. (1966). Konsortsii kak elementyi funktsionalnoy strukturyi biogeotsenozov [Consortia as elements of the functional structure of biogeocenosis]. Trudyi MOIP, 27, 117-126 (in Russian).

Ponomarenko, O. L. (2005). Dynamika funkcionalnogo skladu ugrupovan ptakhiv u indyvidualnykh konsorciyakh lypy sercelystoyi (Tilia cordata) [Dynamics of the birds groups functional composition in individual consortia of linden (Tilia cordata)]. Visnyk Dnipropetrovskogo universytetu. Biologiya. Ekologiya, 13(1), 226-231 (in Ukrainian).

Ponomarenko, O. L. (2007). Formuvannya konsortyvnykh zvyazkiv ptakhiv u indyvidualnykh konsorciyakh klena polovogo (Acer campestre) protyagom jogo ontogenezu [Formation of conservative bird connections in individual consortia of maple (Acer campestre) during its ontogenesis]. Pytannya stepovogo lisoznavstva ta lisovoyi rekultyvaciyi zemel, 11, 127-132 (in Ukrainian).

Ponomarenko, O. L. (2006). Rozvytok konsortyvnykh zviazkiv ptakhiv $\mathrm{v}$ indyvidualnykh konsortsiiakh duba zvychainoho (Quercus robur L.) protiahom yoho ontohenezu [Development of consortium bird connections in individual consortia of oak (Quercus robur L.) during its ontogenesis]. Pytannia stepovoho lisoznavstva ta lisovoi rekultyvatsii zemel, 10, 134-143 (in Ukrainian).

Ramenskiy, L. G., 1952. O nekotoryih printsipialnyih polozheniyah sovremennoy geobotaniki [Some basic principles of modern geobotany]. Bot. Zhurnal, 37(2), 181-201 (in Russian).

Smirnova, O. V., Zaugolnova, L. B., Taronova, N. A., Falikov, L. D. (1976). Kriterii vyideleniya vozrastnyih sostoyaniy i osobennosti hoda ontogeneza u rasteniy razlichnyih biomorf [Criteria for the identification of age-related conditions and features of the ontogenesis course in plants of various biomorphs]. Tsenopopulyatsii rasteniy (osnovnyie ponyatiya i struktura), 1. Moscow. 14-43 (in Russian).

Sukachev, V. N. (1972). Opredelenie ponyatiya «lesnoy biogeotsenoz», ego komponentyi i osnovnyie svoystva [Definition of the term «forest biogeocenosis», its components and basic properties]. Izbrannyie trudyi, 1. Leningrad. 329-356 (in Russian).

Tkachenko, M. E. (1955). Obschee lesovodstvo [Common forestry]. Moscow-Leningrad (in Russian).

Tryfanova, M. V., Kunax, O. M., Zhukov, O. V. (2015). Doslidzhennya konsortyvnyh zvyazkiv u biogeocenozakh ta okhorona pryrody [Investigation of consortial connections in biogeocoenoses and nature protection]. Dnipropetrovsk. 111 (in Ukrainian).

Yuzyk, D. I., Chaplygina, A. B. (2015). Konsortyvni zvyazky polovogo gorobcya (Passer montanus) v umovax lisovykh cenoziv Pivnichno-Skhidnoyi Ukrayiny [Consortia interactions of field sparrow (Passer montanus) in conditions of forest cenosis of the North-Eastern Ukraine]. Berkut, 24(2), 142-147 (in Ukrainian). 